\title{
Communication/Comunicação
}

\section{Prevalence of serum antibodies to hantavirus in a rural population from the Southern State of Santa Catarina, Brazil}

\author{
Prevalência de anticorpos séricos para hantavírus em população rural do extremo sul do Estado \\ de Santa Catarina, Brasil
}

\author{
Gregório Wrublevski Pereiraa ${ }^{1,2,3}$, André Martins Teixeira ${ }^{1,3}$, Mirela Silva de Souza ${ }^{1,3}$, Alixandre Dias Braga ${ }^{1,3}$, \\ Gilberto Sabino dos Santos Junior ${ }^{4,5}$, Glauciane Garcia de Figueiredo ${ }^{4,5}$, Luiz Tadeu Moraes Figueiredo ${ }^{4,6}$ \\ and Alessandra Abel Borges ${ }^{3,7}$
}

\begin{abstract}
Introduction: Rodent-borne hantaviruses cause severe human diseases. We completed a serological survey of hantavirus infection in rural inhabitants of Turvo County, in the southern State of Santa Catarina, Brazil, in which seropositivity for hantavirus was correlated to previous disease in the participants. Methods: The levels of IgG antibodies to hantavirus Araraquara in the sera of 257 individuals were determined using an immunoenzymatic assay. Results: $\operatorname{IgG}$ antibodies to hantavirus were found in $2.3 \%$ of the participants. All seropositive participants reported previous disease with symptoms suggestive of hantavirus cardiopulmonary syndrome. Conclusions: Human infections causing unreported cardiopulmonary syndrome probably occur in the southern State of Santa Catarina.
\end{abstract}

Keywords: Hantavirus. Seroepidemiological studies. Hantavirus pulmonary syndrome.

\section{RESUMO}

Introdução: Hantaviroses são zoonoses de roedores silvestres que causam doenças graves em seres humanos. Este trabalho mostra inquérito sorológico para hantavírus em população rural e periurbana do município de Turvo, Estado de Santa Catarina e a correlação da presença de anticorpos antihantavírus com a história mórbida pregressa dos indivíduos. Métodos: Investigaram-se os 257 participantes do estudo quanto à presença de anticorpos IgG séricos anti-hantavírus Araraquara, por método imunoenzimático. Resultados: A prevalência de anticorpos anti-hantavírus na população foi de $2,3 \%$. Os soropositivos possuíam antecedente nosológico sugestivo de hantavirose pregressa. Conclusões: Os achados mostram a ocorrência de infecções por hantavírus no extremo sul de Santa Catarina.

Palavras-chaves: Hantavirus. Estudos soroepidemiológico. Síndrome pulmonar por hantavirus.

1. Faculdade de Medicina, Universidade do Sul de Santa Catarina, Tubarão, SC 2. Grupo de Pesquisa em Pneumologia e Semiologia, Universidade do Sul de Santa Catarina, Tubarão, SC. 3. Unidade de Pesquisa em Virologia, Universidade do Sul de Santa Catarina, Tubarão, SC. 4. Centro de Pesquisa em Virologia, Faculdade de Medicina, Universidade de São Paulo, Ribeirão Preto, SP. 5. Programa de PósGraduação em Imunologia Básica e Aplicada, Faculdade de Medicina, Universidade de São Paulo, Ribeirão Preto, SP. 6. Departamento de Clínica Médica, Faculdade de Medicina, Universidade de São Paulo, Ribeirão Preto, SP. 7.Laboratório de Pesquisas em Virologia e Imunologia, Instituto de Ciências Biológicas e da Saúde, Universidade Federal de Alagoas, Maceió, AL.

Address to: Dra. Alessandra Abel Borges. Lab. Pesquisas Virologia e Imunologia/ICBS/ UFAL. Pça Afrânio Jorge s/n, Prado, 57010-020 Maceió, AL, Brasil.

Phone: 5582 3336-3444 r: 223; Fax: 5582 3221-2501

e-mail: alessandra.a.borges@gmail.com

Received in 27/10/2010

Accepted in 17/02/2011
Hantaviruses are zoonotic diseases transmitted to humans by the excreta of rodents, the natural reservoirs of these viruses. In the Americas, hantaviruses are associated with the Sigmodontinae subfamily of Muridae rodents ${ }^{1,2}$.

Different species of hantavirus have been identified as the etiological agents responsible for two human diseases: hemorrhagic fever with renal syndrome (HFRS) in Asia and Europe and hantavirus pulmonary syndrome (HPS) in the Americas ${ }^{3}$. HPS was first reported in 1993, and through May 2010, a total of 1,253 cases of HPS have been reported in Brazil, with a case-fatality rate of $39 \%$.

In the State of Santa Catarina (SC), located in the South Region of Brazil, 211 cases of HPS have been recorded since 1999, with 54 human deaths (case-fatality rate of $25.4 \%)^{5}$. The incidence of HPS in SC has increased each year. Currently, SC ranks second among Brazilian states with respect to the number of HPS cases ${ }^{5}$. Hantavirus infections in SC have been documented in the western and central regions of the state, and cases have not been reported in the southern region. However, the antibody levels to hantavirus in the population in the southern region are unknown, and there is no evidence that hantavirus infections do not occur in the southern part of $\mathrm{SC}^{6}$.

Herein, we report the results of a serological survey for hantavirus among individuals living in the rural area of Turvo County in the southern region of SC. This study was approved by the Research Ethics Committee of the University of South of Santa Catarina, process number 08.057.4.01.III. A total of 257 participants voluntarily consented to participate in the study after a brief explanation about its aim. The participants were interviewed individually to obtain information about their past medical history. Data for one participant were also obtained from medical records. In total, 149 (57.9\%) men and 108 (42\%) women, mostly adults younger than 60 years old, participated in the study. Among them, 223 reported exposure to rodents or their excreta at work. After the interview, the blood of the participants was collected, and their sera were tested for hantavirus-specific IgG antibodies.

Sera were tested using an indirect IgG ELISA using the N recombinant ( $\mathrm{rN}$ ) protein of the Araraquara hantavirus (ARAV) as the antigen. This technique has been previously described by Figueiredo et $\mathrm{al}^{7}$. Briefly, polystyrene microtiter plates (Greiner Bio-one, Germany) were coated overnight in a wet chamber at $4^{\circ} \mathrm{C}$ with $2 \mu \mathrm{g} / \mathrm{mL}$ of ARAV rN protein (lines A to D) or with negative 
TABLE 1 - Data for the 6 individuals seropositive for hantavirus from Turvo, State of Santa Catarina, Brazil.

\begin{tabular}{|c|c|c|c|c|c|c|}
\hline Features & $\begin{array}{c}\text { Participant } \\
n=16\end{array}$ & $\begin{array}{c}\text { Participant } \\
\mathrm{n}=17\end{array}$ & $\begin{array}{c}\text { Participant } \\
\text { n }=18\end{array}$ & $\begin{array}{c}\text { Participant } \\
\text { n=19 }\end{array}$ & $\begin{array}{c}\text { Participant } \\
\mathbf{n}=52\end{array}$ & $\begin{array}{c}\text { Participant } \\
\quad \mathbf{n}=\mathbf{8 8}\end{array}$ \\
\hline Age & 54 & 51 & 55 & 38 & 36 & 61 \\
\hline Sex & M & $\mathrm{F}$ & M & M & M & M \\
\hline Current occupation & government employee & maintenance assistant & farmer & farmer & maintenance assistant & farmer \\
\hline Past occupations & farmer and bricklayer & Farmer & - & - & - & - \\
\hline $\begin{array}{l}\text { Symptoms of past illnesses: fever, myalgia, } \\
\text { headache, malaise, dyspnea, oliguria, chest } \\
\text { pain, abdominal pain, vomiting and hypotension }\end{array}$ & yes $^{* *}$ & yes $^{* *}$ & yes $^{* *}$ & yes $^{* *}$ & yes $^{* *}$ & yes $^{* *}$ \\
\hline
\end{tabular}

M: male, F: female. ${ }^{*}$ The participant reported performing all of these high-risk activities, ${ }^{* *}$ The participant reported having had almost all of these symptoms during an illness episode in the past.

control antigen (purified plasmid pET200D with no insert - lines E to $H)$. Then the microplate wells were washed six times with PBST (phosphate-buffered saline [PBS]-1\% Tween 20) and incubated with a blocking solution ( $10 \%$ skim milk powder in PBST) at $37^{\circ} \mathrm{C}$ for $2 \mathrm{~h}$. After washing the plates six times with wash buffer, the samples were diluted 1:100 in blocking solution and added to the plates at a volume of $50 \mathrm{uL} /$ well. The plates were incubated for $1 \mathrm{~h}$ at $37^{\circ} \mathrm{C}$ and washed, and then peroxidase-labeled affinity-purified goat anti-human IgG antibody (Sigma, USA) diluted 1:2,000 in blocking solution was added $(50 \mathrm{uL} /$ well $)$. After incubation for $1 \mathrm{~h}$ at $37^{\circ} \mathrm{C}$, the plates were washed, and $50 \mathrm{uL} /$ well of 2,2'-azinobis (3-ethylbenzthiazoline6-sulfonic acid)(ABTS) substrate (KPL $\left.{ }^{\oplus}, \mathrm{EUA}\right)$ was added. After appearance of the color, the plates were read in a spectrophotometer (Flow, Finland) at $405 \mathrm{~nm}$. Values were expressed as the optical density (OD) obtained with ARAV rN antigen minus the OD values for the control antigens. The cut-off value of the test was determined by the mean plus three standard deviations of the ODs obtained from at least four negative control serum samples. Seropositive samples were tittered from dilutions of 1:100 to $1: 25,600$.

Six participants had IgG antibodies to hantavirus $(2.3 \%$ seropositivity). This prevalence is similar to that observed in previous studies in areas of Brazil with HPS reported cases ${ }^{8,9}$. The titers of the positive sera were $800,1,600$ and 3,200. These serum titers can be considered high, although they did not allow the determination of the time elapsed since infection. In a similar study performed in Jardinópolis county, State of São Paulo, the highest serum titers for hantavirus were $400^{10}$.

All six hantavirus-seropositive participants lived in rural or periurban areas, and three of them were farmers. Except for one, they all performed high-risk activities and had contact with rodents as part of their work. Two of the positive individuals cleaned silos and bunkers and reported having killed more than 60 rodents on some occasions. In addition, all seropositive participants reported a previous acute febrile illnesses that could have been caused by hantavirus. These data are shown in Table $\mathbf{1}$.

The only female among the seropositive subjects reported a previous disease that supposedly happened one week after being bitten by rats. This woman was 41 years old, a farmer and a housewife. She was admitted to the hospital of Turvo County in October 1999 complaining of dyspnea and fever. She reported intense and widespread myalgia, fever during the last five days $\left(38.5^{\circ} \mathrm{C}\right)$ and dyspnea when performing routine activities. The illness evolved with remarkable dyspnea on the second day of hospitalization. At this time, a chest radiograph showed bilateral infiltrates that were more prominent in the bases, and she exhibited hemoconcentration (Ht 51\%) and leukocytosis $\left(19,000\right.$ cells $\left./ \mathrm{mm}^{3}\right)$ with a left shift. The patient was treated with levofloxacin, paracetamol, $100 \% \mathrm{O}_{2}$ supplied by a Venturi mask and intravenous fluid. With diagnosis of viral pneumonia, the patient was moved to an intensive care facility in a hospital in the City of Porto Alegre, where she stayed for 6 days, followed by 10 days in the regular ward of the hospital.

A previous infection by hantavirus was observed in $2.3 \%$ of the participants of the survey, showing that these viruses probably produce human infections in the southern region of SC, where HPS has not yet been reported. At least one of the seropositive participants had a previous unconfirmed disease compatible with HPS. Thus, it is important to inform local clinicians about the epidemiology, signs and symptoms of HPS so that this disease is included in the differential diagnosis of pneumonia with acute respiratory failure.

\section{ACKNOWLEDGMENTS}

We are grateful to Radio Imigrantes (AM $1550 \mathrm{MHz}$ ) and Secretaria Municipal de Saúde de Turvo/SC for their support in advertising this study. We thank the nursing technicians for their assistance in collecting the blood samples and Maria Elisa Favarin for the assistance with the logistics of data collection. We thank the medical students of the Universidade do Sul de Santa Catarina for their support with the interviews.

\section{CONFLICT OF INTEREST}

The authors declare that there is no conflict of interest.

\section{FINANCIAL SUPPORT}

This work was funded by the Fundação de Amparo à Pesquisa do Estado de São Paulo (FAPESP) and the Universidade do Sul de Santa Catarina (UNISUL). The study was granted an Undergraduate Research Scholarship (PIBIC) by the Conselho Nacional de Desenvolvimento Científico e Tecnológico ( $\mathrm{CNPq})$. 


\section{REFERENCES}

1. Nichol ST. Genetic analysis of hantaviruses and their host relation-ships. In: Saluzzo JF, Dodet B, editors. Factors in the emergence and control of rodentborne viral diseases. Paris: Elsevier; 1999. p. 99-109.

2. Figueiredo LTM, Moreli ML, Sousa RLM, Borges AA, Figueiredo GG, Machado A, et al. Hantavirus Pulmonary Syndrome, Central Plateau, Southeastern, and Southern Brazil Emerg Infect Dis 2009; 15:561-567.

3. Mertz GJ. Bunyaviridae: Bunyaviruses, Phleboviruses, Nairoviruses and Hantaviruses. In: Richman DD, Whitley RJ, Hayden FG, editors. Clinical virology. $2^{\text {th }}$ ed. Washington, DC: ASM Press; 2002. p. 921-948.

4. Figueiredo LTM, Moreli ML, Campos GM, Sousa RL. Hantaviruses in São Paulo State, Brazil. Emerg Infect Dis 2003; 9:891-892.

5. Ministério da Saúde. Informes Epidemiológicos: Hantavirose por Unidade Federada Provável de Infecção e Ano. Brasil, 1993 - 2010. Brasília: Ministério da Saúde. Área Técnica de Hantaviroses; 2010.

6. Secretaria de Estado da Saúde de Santa Catarina. A hantavirose no Estado de Santa Catarina, 1999 - 2009. Florianópolis: Secretaria de Estado da Saúde. Sistema Único de Saúde. Superintendência de Vigilância em Saúde. Diretoria de Vigilância Epidemiológica; 2009.

7. Figueiredo LTM, Moreli ML, Borges AA, Souza RLM, Aquino VH. Expression of a hantavirus $\mathrm{N}$ protein and its efficacy as antigen in immune assays. Braz J Med Biol Res 2008; 41:596-599.

8. Campos GM, Sousa RLM, Badra SJ, Pane C, Gomes UA, Figueiredo LTM Serological survey of hantavirus in Jardinópolis county, Brazil. J Med Virol 2003; 71:417-422.

9. Holmes RR, Boccanera R, Figueiredo LTM, Mancano SR, Pane C. Seroprevalence of human hantavirus infection in the Ribeirao Preto region of Sao Paulo State, Brazil. Emerg Infect Dis 2000; 6:560-561.

10. Campos GM. Estudo clínico-epidemiológico sobre a hantavirose na região de Ribeirão Preto, SP [Dissertação de Mestrado]. [Ribeirão Preto]: Faculdade de Medicina de Ribeirão Preto, Universidade de São Paulo; 2002. 71 p. 